\title{
PENGARUH PEMBERDAYAAN PEGAWAI TERHADAP KINERJA ORGANISASI KANTOR KECAMATAN HARUYAN KABUPATEN HULU SUNGAI TENGAH
}

\author{
Erna Suriyani \\ E-mail: ernasuryani65@yahoo.co.id
}

Fakultas Ilmu Administrasi Universitas Achmad Yani Banjarmasin

\begin{abstract}
The purpose of this study is to determine the effect of empowerment of employees on organizational performance at the District Office Haruyan Hulu Sungai Tengah. The type of research used is explanatory, while the research approach is a quantitative approach.

The findings of research that is at a significant level of $5 \%$ proved to have an effect of empowerment of employees who viewed from the desire to the performance of Haruyan District Office, while for $1 \%$ it turned out that the empowerment of pegawi does not affect the performance of the organization. At a significant level of $5 \%$ proved to have an effect of employee empowerment viewed from trust to organizational performance, while for $1 \%$ no effect. At a significant level of $5 \%$ proved to have an effect variable employee empowerment seen from confident to the performance of the organization, while $1 \%$ no effect. And there is influence empowering employees seen from the cridibility of organizational performance at a significant level of $5 \%$, while at $1 \%$ no effect. At a significant level of $1 \%$ and $5 \%$ proved to have an effect of employee empowerment seen from accountability to organizational performance. And at a significant level of $5 \%$ proved to have an effect of empowering employees viewed from comunication to organizational performance, while at $1 \%$ no effect.
\end{abstract}

Keywords: Employee Empowerment and Organizational Performance

\section{PENDAHULUAN}

Sebagai upaya tercapainya

suatu kinerja organisasi yang tinggi

baik itu lembaga pemerintah atau non-pemerintah maka hal utama yang harus dimiliki adalah sumber daya manusia yang berkualitas.

Dengan demikian aparatur

pemerintah pasti diharapkan menjadi aparatur yang memiliki kemampuan yang tinggi, sehingga tercapainya kinerja suatu organisasi 
dengan baik. Kinerja organisasi yang tinggi menunjukkan bahwa hasil kerja yang diproleh dari satu orang atau sejumlah orang di dalam suatu lembaga sesuai dengan standar yang ditentukan.

Untuk memperoleh itu hal tersebut maka aparatur harus mempunyai kemampuan dan keterampilan dapat menunjang penyelesaikan pekerjaan. Aparatur pemerintah sangat diharapkan mempunyai inovasi dan kreativitas yang tinggi, serta dalam menyelesaikan pekerjaan harus sesuai dengan waktu yang telah ditentukan. Agar aparatur pemerintah tersebut mampu melaksanakan tugas sebaik-baiknya maka perlu didorong dengan cara memberdayakan mereka.

Kantor Kecamatan Haruyan adalah juga lembaga pemerintah yang menghendaki kinerja organisasinya tinggi. Kendati demikian dari pengamatan sementara terlihat bahwa masih kurang maksimalnya pelaksanaan tugas sebagian pegawai, seperti masih adanya penyelesaian pekerjaan yang belum tepat waktu, pegawai belum semuanya dapat menyelesaikan pekerjaan dengan volume yang tinggi dan dalam penyelesaian pekerjaan yang menjadi tugasnya sebagian besar bukan dilakukan atas gagasan sendiri. Di samping itu nampaknya belum terbangunnya suasana untuk menciptakan temuan baru untuk menyelesaikan pekerjaan serta belum tersedianya akses informasi dengan baik.

Beranjak dari permasalahan tersebut penelitian ini bertujuan untuk menguji dan menganalisis tentang pengaruh pemberdayaan pegawai terhadap kinerja organisasi pada kantor Kecamatan Haruyan tersebut. 


\section{TINJAUAN TEORITIS}

A. Pemberdayaan Pegawai.

Menurut Tjiptono (2001:108) mengemukakan bahwa " pemberdayaan adalah upaya memberikan

otonomi,kepercayaan atasan kepada bawahan, serta mendorong mereka untuk kreatif. Hal ini dimaksudkan oleh tjiptono untuk merampungkan pekerjaannya sebaik mungkin". Pegawai diberi kebebasan atau keleluasaan untuk mengambil tindakan-tindakan yang dipandang tepat dalam rangka melayani pelanggan, termasuk menangani keluhan mereka." Berdasarkan pemikiran dimaksud, dapat dijelaskan bahwa otonomi diberikan kepada pegawai adalah dalam arti pegawai diberikan hak,wewenang dan kewajiban serta diberi dukungan peralatan yang dibutuhkan, untuk mengatur dan mengurus tugas- tugas sesuai dengan tanggungjawabnya berdasarkan ketentuan yang diberlakukan dalam memberikan pelayanan keopada masyarakat maupun kepada perusahaan sebagai mitra kerja. Menurut Edi Suharto, (2005: 57), secara konseptual pemberdayaan atau pemerkuasaan (empowerment) berasal dari kata power (kekuasaan atau keberdayaan).

Syarafat Khan (dalam Kadarisman, 2012:260) menawarkan sebuah model pemberdayaan yang dapat dikembangkan dalam sebuah organisasi .

$$
\text { Adapun }
$$
model pemberdayaan Khan :

1. Keinginan (Desire)

Yakni adanya keinginan dari manajemen untuk mengikutsertakan para pegawai dan keinginan pendelegasian. Hal ini antara lain : 
a) Memperkecil directive personality dan memperluas kesempatan kerja.

b) Mendorong terciptanya persfektif baru dan memikirkan kembali strategi kerja.

2. Kepercayaan (Trust)

Trust adalah membangun kepercayaan antara manajemen dan pegawai. Adanya rasa saling percaya di antara sesama anggota organisasi akan tercipta suasana yang kondusip, tidak adanya rasa takut bagi pegawai dalam memberikan saran-saran dan berjalan pertukaran informasi dengan baik. Apabila kepercayaan itu sudah tidak ada atau diri pegawai tersebut sudah tidak lagi dipercaya, maka sulit bagi pegawai untuk mampu menyelesaikan pekerjaan yang dibebankan kepadanya, termasuk kepercayaan yang melekat pada pribadi masingmasing pejabat yang memduduki jabatan adalah merupakan suatu kepercayan diberikan pimpinan kepada pegawai tersebut. Hal- hal yang termasuk dalam trust antara lain:

a) Memberikan kesempatan kepada para pegawai untuk terlibat dalam pembuatan kebijakan.

b) Menyediakan sumber daya dan waktu yang mencukupi bagi pegawai dalam menyelesaikan pekerjaan.

c) Melaksanakan pelatihan bagi pegawai sesuai dengan kebutuhan kerja..

3. Percaya diri (Confident)

Adapun tindakan yang menimbulkan percaya diri pegawai antara lain :

a) Memiliki kemampuan untuk menyelesaikan pekerjaan tepat waktu.

b) Memiliki kreatifitas kerja 
c) Memperluas tugas dan membangun jaringan mitra kerja.

d) Menyelesaikan permasalahan dalam unit kerja.

4. Kredibilitas (Credibility)

Mencipta organisasi yang memiliki kepercayaan maka diperlukan kualitas, kapabilitas atau kekuatan untuk menimbulkan kepercayaan

5. Dapat dipertanggungjawabkan (Accountability)

Accountability adalah yakni pertanggungjawaban wewenang yang diberikan pegawai pada.Dengan menetapkan secara konsisten dan jelas tentang peran, standart dan tujuan penilaian terhadap kinerja dalam penyelesaian dan tanggungjawab terhadap wewenang yang diberikan. Hal yang termasuk dalam accountability antara lain :

a) Melibatkan pegawai membuat ukuran atau standart pekerjaan. b) Memberikan saran dan bantuan kepada pegawai dalam menyelesaikan beban kerjanya.

c) Menyediakan waktu dan periode pemberian feetback.

6. Komunikasi (Communication) Tahap ini merupakan tahap terakhir, diharapkan adanya komunikasi yang terbuka untuk menciptakan saling memahami antara pegawai dengan manajemen. Keterbukaan ini dapat mewujudkan dengan adanya kritik dan saran terhadap hasil dan prestasi yang dilakukan pegawai. Hal yang termasuk dalam commucation antara lain :

a) Menetapkan kebijakan open door communication.

b) Mendapatkan informasi dan

c) Mendiskusikan permasalahan secara terbuka.

B. Kinerja Organisasi

Menurut Chaini Nasucha dalam Sinambela (2012: 186) Kinerja organisasi di definisikan 
sebagai efektifitas organisasi secara menyeluruh untuk memenuhi kebutuhan yang ditetapkan dari setiap kelompok yang berkenaan melalui usahausaha yang sistematik dan meningkatkan kemampuan organisasi secara terus menerus untuk mencapai kebutuhannya secara efektif

$$
\begin{aligned}
& \text { Menurut Sinambela } \\
& \text { (2012) Kinerja merupakan } \\
& \text { pelaksanaan suatu pekerjaan dan } \\
& \text { penyempurnaan pekerjaan } \\
& \text { tersebut } \\
& \text { sesuai } \\
& \text { tanggungjawabnya,sehingga } \\
& \text { dapat mencapai hasil sesuai } \\
& \text { dengan yang diharapkan. } \\
& \text { Sementara itu menurut Wibawa } \\
& \text { dalam Hayat (2017: } 59 \text { ) } \\
& \text { mengungkapkan bahwa kinerja } \\
& \text { adalah hasil kerja dari suatu }
\end{aligned}
$$

dapat ditemukan dalam aturan pembentukan organisasi melalui visi,misi,tujuan dan strategi yang digunakan dan harapan yang ingin dihasilkan. Kinerja bukan yang yang objektif,tetapi subyektif dalam prinsipnya,yaitu tergantung dari orang yang menilai, waktu dan tempat penilaian

Menurut Byars dan Rue (2008: 216) "Performance refers to degree of employee's job.It reflects how well an employee is fulfilling the requirement of a jo". Pendapat Byars dan Rue diartikan bahwa kinerja mengacu pada derajat tingkat penyesuaian tugas yang melengkapi pekerjaan pegawai. Indikator kinerja menurut Byars dan Rue (2008: 216) adalah" Performance in a given situation can be viewed as resulting from the interrelationships among effort,abilities, and role 
perception"( kinerja dalam situasi tertentu dapat dilihat sebagai akibat dari hubungan balik antara usaha,kemampuan dan persepsi tugas )

Uraian Indicator dari kinerja tersebut adalah sebagai berikut :

1. Effort (Usaha): " result from being motivated,refers to the amount of enery (physical and/or mental ) an individual uses in performing a task" (hasil dari motivasi, mengacu pada energy( fisik dan/atau mental) individu yang digunakan dalam pelaksanaan tugas kerja).

2. Ability (kemampuan): Abilites are personal characteristics used in performing a job.Abilities usually do not fluctuate widely over short periods of tim" ( kemampuan merupakan criteria seseorang yang digunakan dalam melaksanakan suatu pekerjaan. Kemampuan pada umumnya tidak terlalu banyak berubah dalam waktu yang singkat).

3. Role (task) perceptions (persepsi tugas): “Role (tast) perceptions refer to the direction(s) in wich individuals believe they should channel their effort on their jobs.the activities and behaviors people believe are necessary in the performance of their jobs define their role perceptions" ( menunjukkan arah para pegawai memahami kemana seharusnya mereka menyalurkan usahanya untuk keperluan pekerjaannya.Aktivitas dan sikap percaya para pegawai juga di perlukan dalam pelaksanaan pekerjaaan yang sesuai dengan persepsi perannya masing-masing)

Sedangkan menurut Flippo (1987), criteria kinerja yang paling umum digunakan untuk 
menilai atau mengukur kinerja individu pegawai meliputi empat faktor yaitu :

1. Kualitas atau mutu kerja: yaitu

ketepatan,keterampilan,keteli tian, dan kerapian hasil kerja;

2. Kuantitas kerja: yaitu tidak hanya menyangkut tugastugas regular.tetapi juga kecepatan dalam menyelesaikan tugas-tugas ekstra atau mendesak.

3. Ketangguhan atau keuletan,yaitu meliputi mengikuti perintah, kebiasaan yang baik, inisiatif, ketepatan waktu, dan kehadiran.

4. Sikap atau attitude yaitu sikap terhadap perubahan pekerjaan dan terhadap teman kerja,serta kerjasama.

Berdasarkan hal tersebut maka dalam penelitian ini kinerja organisasi akan diukur dari : kualitas, Ability (kemampuan), Kuantitas Kerja, Ketangguhan dan Sikap.

C. Pengaruh Pemberdayaan terhadap kinerja pegawai.

Menurut Dale Yoder, Alfred Laitener dan Joseph triffin (dalam sartono : 211:11) tujuan pemberdayaan pegawai adalah untuk menambah pengetahuan, menambah keterampilan dan mengubah sikap. Beranjak dari pendapat tersebut diatas maka pegawai yang memiliki keterampilan, pengetahuan yang luas terutama yang berkaitam dengan pekerjaan serta memiliki prilaku yang baik akan menghasilkan kinerja pegawai yang lebih baik. Penelitian Adhitya Nugraha (2016) dengan judul Analisis Pengaruh Pemberdayan Sumber daya manusia terhadap Kinerja pegawai pada Kecamatan Banjar Kota Banjar. Hasilnya menunjukan besaran nilai 
signifikan terhadap kinerja judul penelitian Pengaruh pegawai secara optimal yaitu Motivasi dan Pemberdayaan $60,83 \%$ artinya pengaruh karyawan Terhadap Kinerja pemberdayaan sumberdaya karyawan PT.HD Motor 99 manusia menunjukan positif). Denpasar, bahwa motivasi dan Sementara itu hasil penelitian pemberdayaan karyawan secara dari Adetya Vlanty Putri dan I signifikan berpengaruh positif Komang Ardana (2016) dengan terhadap kinerja karyawan.

D. Model Penelitian

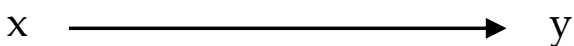

Pemberdayaan Pegawai

1. Disire

2. Trust

3. Confident

4. Credibility

5. Accountabbility

6. Comunication
Kinerja Organisasi

1. Kualitas Kerja

2. Ability

3. Kuantitas Kerja

4. Ketangguhan

5.Sikap

\section{METODOLOGI PENELITIAN}

Tipe penelitian yang digunakan pada penelitian ini adalah tipe Eksplanatory dan pendekatan yang digunakan adalah pendekatan kuantitatif. Untuk membuktikan ada tidaknya pengaruh pemberdayaan pegawai dengan Kinerja kantor Kecamatan Haruyan akan digunakan model Chi Kuadrat dengan rumus:

$\lambda_{0}{ }^{2}=\sum(\underline{0-E})^{2} \quad($ Sutrisno Hadi,2000:21) 
Keterangan :
$\lambda_{\mathrm{n}}{ }^{2}=$ Chi Kuadrat
$\mathrm{O}=$ Frekwensi yang diproleh
$\mathrm{E}=$ Frekwensi yang diharapkan.

\section{IV . HASIL- HASIL PENELITIAN \\ DAN PEMBAHASAN}

a. Pengaruh

Pemberdayaan

Pegawai (dilihat dari faktor Disire) Terhadap kinerja Organisasi pada kantor Kecamatan Haruyan Hulu Sungai Tengah

Dari hasil perhitungan uji statistik dengan Chi Kuadrat ternyata $\lambda_{0^{2}}=10,76$ dan derajat bebas $(\mathrm{V})=(\mathrm{b}-1)(\mathrm{k}-1)=4$.

Dalam tabel Chi kuadrat untuk tingkat signifikan 5\% dengan derajat bebas (db) 4 adalah 4,49 dengan derajat bebas 4, sehingga nilai test sebesar 10,76 tersebut untuk nilai 5\% lebih besar dari 4,49 yang berarti 10,76 itu berada di daerah penolakan Ho. Akibatnya Ho ditolak dan Ha diterima. Dengan kata lain terbukti ada pengaruh faktor Pemberdayaan Pegawai (dilihat dari Desire)
Terhadap kinerja Organisasi pada kantor Kecamatan Haruyan.

Apabila nilai $1 \%$ dengan $\mathrm{db} 4$ adalah 13,3 sehingga nilai ters 10,76 tersebut lebih kecil dari 13,3 yang berarti 10,76 itu berada pada penolakan Ha, akibatnya Ho diterima dan berarti terbukti tidak ada pengaruh faktor Pemberdayaan - Pegawai (dilihat dari Desire) Terhadap kinerja Organisasi.

\section{b. Pengaruh faktor Pemberdayaan} Pegawai (dilihat dari Trust) Terhadap kinerja Organisasi.

Berdasarkan hasil perhitungan uji statistik dengan Chi Kuadrat ternyata $\lambda_{0^{2}}=7,22$ dan derajat bebas $(\mathrm{V})=(\mathrm{b}-1)(\mathrm{k}-1)=4$.

Dalam tabel Chi kuadrat untuk nilai $5 \%$ dengan derajat bebas 4 adalah 4,49 dengan derajat bebas 4, sehingga nilai test sebesar 10,76 tersebut untuk nilai 5\% lebih besar dari 4,49 yang berarti 7,22 itu 
berada di daerah penolakan Ho. dari 4,49 yang berarti 10,76 itu Akibatnya Ho ditolak dan Ha berada di daerah penolakan Ho. diterima. Ini berarti ada pengaruh Akibatnya Ho ditolak dan Ha faktor Pemberdayaan Pegawai (dilihat dari Trust) Terhadap kinerja Organisasi.

Apabila nilai $1 \%$ dengan $\mathrm{db} 4$ adalah 13,3 sehingga nilai ters 7,22 tersebut lebih kecil dari 13,3 yang berarti 7,22 itu berada pada penolakan $\mathrm{Ha}$ akibatnya Ho diterima, berarti tidak ada pengaruh faktor Pemberdayaan Pegawai (dilihat dari Trust) Terhadap kinerja Organisasi.

\section{c. Pengaruh Pemberdayaan \\ Pegawai (dilihat dari faktor Confident ) Terhadap kinerja Organisasi}

Berdasarkan hasil perhitungan uji statistik dengan Chi Kuadrat ternyata $\lambda_{0^{2}}=10,756$ dan derajat bebas $(\mathrm{V})=(\mathrm{b}-1)(\mathrm{k}-1)=4$.

Dalam tabel Chi kuadrat untuk nilai $5 \%$ dengan derajat bebas 4 adalah 4,49 dengan derajat bebas 4, sehingga nilai test sebesar 10,76 tersebut untuk nilai 5\% lebih besar diterima. Dengan kata lain terbukti ada pengaruh faktor Pemberdayaan Pegawai (dilihat dari Confident) Terhadap kinerja Organisasi.

Apabila nilai $1 \%$ dengan db 4 adalah 13,3 sehingga nilai ters 10,756 tersebut lebih kecil dari 13,3 yang berarti 10,756 itu berada pada penolakan $\mathrm{Ha}$, akibatnya Ho diterima dengan kata lain terbukti tidak ada pengaruh faktor Pemberdayaan Pegawai (dilihat dari Confident) Terhadap kinerja Organisasi.

\section{d. Pengaruh} Pemberdayaan Pegawai (dilihat dari Credibility) Terhadap kinerja Organisasi

Berdasarkan hasil perhitungan uji statistik dengan Chi Kuadrat ternyata $\lambda_{0^{2}}=7,19$ dan derajat bebas $(\mathrm{V})=(\mathrm{b}-1)(\mathrm{k}-1)=4$.

Dalam tabel Chi kuadrat untuk nilai $5 \%$ dengan derajat bebas 4 adalah 4,49 dengan derajat bebas 4, 
sehingga nilai test sebesar 7,19 tersebut untuk nilai 5\% lebih besar dari 4,49 yang berarti 7,19 itu berada di daerah penolakan Ho. Akibatnya Ho ditolak dan $\mathrm{Ha}$ diterima. Dengan kata lain terbukti ada pengaruh faktor Pemberdayaan Pegawai (dilihat dari Cridibility) Terhadap kinerja Organisasi.

Apabila nilai 1\% dengan db 4 adalah 13,3 sehingga nilai ters 7,19 tersebut lebih kecil dari 13,3 yang berarti 7,19 itu berada pada penolakan $\mathrm{Ha}$, akibatnya Ho diterima dengan kata lain terbukti tidak ada pengaruh faktor Pemberdayaan Pegawai (dilihat dari Cridibility) Terhadap kinerja Organisasi pada kantor Kecamatan Haruyan.

\section{e. Pengaruh Pemberdayaan Pegawai (dilihat dari Accountability ) Terhadap kinerja Organisasi}

Berdasarkan hasil perhitungan uji statistik dengan Chi Kuadrat ternyata $\lambda_{0^{2}}=20$ dan derajat bebas $(V)=(b-1)(k-1)=4$
Dalam tabel Chi kuadrat untuk nilai $5 \%$ dengan db 4 adalah 4,49 dan 1\% adalah 13,3 sehingga nilai test sebesar 20 adalah lebih besar dari 4,49 dan $13,3(4,49<20>13,3)$ yang berarti 20 itu berada di daerah penolakan Ho. Akibatnya Ho ditolak dan Ha diterima. Dengan kata lain baik $1 \%$ maupun $5 \%$ terbukti ada pengaruh faktor Pemberdayaan Pegawai (dilihat dari Accountability) Terhadap kinerja Organisasi pada kantor Kecamatan Haruyan.

\section{f. Pengaruh Pemberdayaan Pegawai (dilihat dari Comunication) Terhadap kinerja Organisasi}

Berdasarkan hasil perhitungan uji statistik dengan Chi Kuadrat ternyata $\lambda_{0^{2}}=12,17$ dan derajat bebas $(\mathrm{V})=(\mathrm{b}-1)(\mathrm{k}-1)=4$.

Dalam tabel Chi kuadrat untuk nilai $5 \%$ dengan derajat bebas (db) 4 adalah 4,49, sehingga nilai test sebesar 12,17 lebih besar dari 4,49. Hal ini membuktikan ada pengaruh faktor Pemberdayaan Pegawai 
(dilihat dari Comunication)

Terhadap kinerja Organisasi pada kantor Kecamatan Haruyan .

Apabila nilai 1\% dengan db 4 adalah 13,3 sehingga nilai test 12,17 tersebut lebih kecil dari 13,3 yang berarti 12,17 itu berada pada penolakan $\mathrm{Ha}$, akibatnya Ho diterima dengan kata lain terbukti tidak ada pengaruh faktor Pemberdayaan Pegawai (dilihat dari Comunication) Terhadap kinerja Organisasi pada kantor Kecamatan Haruyan.

\section{KESIMPULAN}

1. Pada tingkat signifikan 5\% terbukti ada pengaruh faktor Pemberdayaan Pegawai (dilihat dari Desire) Terhadap kinerja Organisasi sedangkan untuk 1\% tidak ada.

2. Pada tingkat signifikan 5\% terbukti ada pengaruh faktor Pemberdayaan Pegawai (dilihat dari Trust) Terhadap kinerja Organisasi pada kantor
Kecamatan sedangkan untuk 1\% terbukti tidak ada

3. Pada tingkat signifikan 5\% terbukti ada pengaruh faktor Pemberdayaan Pegawai (dilihat dari Confident) Terhadap kinerja Organisasi sedangkan 1\% tidak ada .

4. Pada tingkat signifikan 5\% terbukti ada pengaruh faktor Pemberdayaan Pegawai (dilihat dari Cridibility) Terhadap kinerja Organisasi pada kantor Kecamatan Haruyan dan 1\% tidak ada.

5. Pada tingkat signifikan $5 \%$ dan $1 \%$ terbukti ada pengaruh faktor Pemberdayaan Pegawai (dilihat dari Accountability) Terhadap kinerja Organisasi pada kantor Kecamatan Haruyan .

6. Pada tingkat signifikan 5\% terbukti ada pengaruh faktor Pemberdayaan Pegawai (dilihat dari Comunication) Terhadap kinerja Organisasi pada kantor 
Kecamatan Haruya sedangkan

$1 \%$ tidak ada.

Saran

7. Pemberdayaan pegawai dengan cara melibatkan pegawai atau memberikan kesempatan kepada pegawai untuk

mengindentifikasikan

permasalahan yang dihadapi dan melibatkan dalam pengambilan keputusan, melalui menggali pendapat dan saran pegawai.

\section{DAFTAR PUSTAKA}

Byars, Lyold Land Rue, Leslie W, 2008, human Resource manajement, ninth Edition, NewYork: The McGraw-Hill Companies, inc.

Edi, Suharto, 2005, Pembangunan Kebijakan dan Kesejahteraan Sosial, Mirzan, Bandung.

Hayat, 2017, Manajemen Pelayanan Publik, PT Rajagrafindo Persada, Jakarta.

Hadi ,Sutrisno Hadi,2000, Statistik 2, Yayasan Penerbit Fakultas Psikologi Universitas Gajah Mada, Jakarta.
Kadarisman, M.2012, Manajemen Sumber Daya Manusia, Jakarta, PT.Raja Grafindo Persada.

Moleong,J,Lexy,2001,Metodologi Penelitian kualitatif,remaja Rosdakarya, Bandung.

Putri, Adetya Vlanty dan Ardana, I Komang 2016 , Pengaruh Pemberdayaan Karyawan Terhadap Kinerja Karyawan PT.HD Motor 99 Denpasar,EJurnal Manajemen Unud,Volume 5, no 11, 2016: 7251-7279, I

Sartono, Budi 2011. Pengaruh Leader-member Exchange pada hubungan Kepercayaan Manajerial dan Pemberdayaan Pegawai (Studi Pada Sekretariat daerah kabupaten Kerinci). Online

Tjiptono, Fandi, 1996, Total Quality Manajement,Cetakan Pertama,Jokjakarta:Penerbit Andi. 